\title{
Luther and the Law in the Lutheran Church of Uganda
}

Authors:
Enoch Ekyarikunda ${ }^{1}$
Ernest van Eck'
Affiliations:
'Department of New
Testament Studies, Faculty of
Theology, University of
Pretoria, South Africa
Project Leader: E. van Eck
Project Number: 2400030
Description:
Enoch Ekyarikunda is part
of the research project,
'Socio-Cultural Readings',
directed by Prof. Dr Ernest
van Eck, Department of
New Testament Studies,
Faculty of Theology,
University of Pretoria.
mobile device
to read online.
Corresponding author:
Enoch Ekyarikunda,
enochmacben@yahoo.com
Read online:
Dates:
Received: 12 Nov. 2015
Accepted: 15 Jan. 2016
Published: 26 May 2016
How to cite this article:
Van Eck, E. \& Ekyarikunda, E.,
2016, 'Luther and the Law in
the Lutheran Church of
Uganda', HTS Teologiese
Studies/Theological Studies
$72(1)$, a3251. http://dx.doi.
org/10.4102/hts.v72i1.3251
Copyright:
C 2016. The Authors.
Licensee: AOSIS. This work
is licensed under the
Creative Commons
Attribution License.

This article investigates the role of the Law in the Lutheran Church of Uganda. It investigates how the Law is understood and lived among Lutherans in Uganda. Luther, the sixteenthcentury Reformer, understood and interpreted the Law in terms of the social and cultural context of his time. Luther's background is very different and so much removed from the African context in which the Ugandan Lutherans find themselves today. Therefore, can the Lutheran Church of Uganda have the same understanding and interpretation of the Law as the Reformer? Is Luther's sixteenth-century European understanding of the Law applicable to the current Lutherans in Africa, specifically in the Lutheran Church of Uganda? This article examines the social and cultural context of Lutherans in Uganda and determines how it affects their understanding and interpretation of the Law. The article aims to demonstrate that the social and cultural context of the people plays an important role in the way the Christian life is conducted. This article appeals to Paul's situation in Galatians to prove this point.

\section{Introduction}

With all that has been written on the Law one wonders if there is anything left to be said. It sounds to be a boring topic to write about the Law, especially with so many volumes already written by reputable scholars. However, the understanding and application of the Law varies from one context to another. It is not a one-size-fits-all situation. The cultural and social contexts of different people have to be taken into consideration when it comes to the understanding and application of the Law.

For the sake of clarity, 'Law' in this article is defined as that which refers to what God commands and demands from his people; what God requires from us in the Holy Scriptures. The Law is anything that is not gospel. The Law includes the ceremonial laws that apply only to the Jews, as well as the Decalogue or the Ten Commandments that apply to all believers. Under 'law' is understood what is demanded by the civil government. This term applies to what the civil government uses to rule the people. These may include the laws of nature, and laws put up by man to govern a specific community. Finally, the Lutheran Church of Uganda refers to the body of Lutherans in Uganda. It is a national church consisting of theologians, pastors, teachers and all members of the Lutheran Church in Uganda.

\section{Luther and the Law}

Luther's understanding of the Law is dependent on Paul. His view of the Law is in line with the way Paul understood it. Luther contrasts the Law to faith, based on his understanding of Paul's letter to the Galatians in which Paul found a gracious God. ${ }^{1}$ Luther, in his table talk of 1532 said: 'The Epistle to the Galatians is my epistle, to which I am betrothed. It is my Katie von Bora' (Luther 1963:ix). In Galatians, Luther found a solution to his troubled conscience. Luther found consolation in Galatians after he had failed to find comfort in the monastery, having been driven there by the promise he had made to St. Anne, 'Help me, St. Anne, I will be a monk' (Brecht 1985:48). Thinking that life in the monastery was more pleasing to God than that of a common Christian, Luther as a monk tried to please God by all kinds of works. He realised very soon, however, that this was impossible, for the more he tried to please God with his works the more burdened his conscience became (Luther 1964:13). Luther then found consolation in Paul's statement of justification by faith apart from the works of the Law. In Paul, Luther read: 'For in the gospel a righteousness from God is revealed, a righteousness that is by faith from first to last, just 1.Stendahl (1963:203) states that Luther was on the quest to find a gracious God since all he felt was guilt and condemnation in his heart
because of the practice of self-examination. Paul's statement on justification by faith alone without the works of the Law provided the needed relief. 
as it is written: "The righteous will live by faith"' (Rm 1:17, NIV; cf. Gl 3:11). Through Paul's letters, Luther came to the full knowledge of how one is justified before God, not because of one's deeds, but because of faith in Christ. This, for Luther, was 'the gate to paradise' (Luther 1960a:337). Luther perceived Paul to be in the same situation as himself. He understood Paul's argument to be directed against Jewish legalism, although this was not the case. Luther imposed his own context on Paul's argument.

Besides this, Luther understood what the Law is and for what purpose it was given. Luther (1963:122-123) understood that the Law and its works do not justify people before God, but justification is only by God's grace through faith in Christ Jesus. God gives grace to his people who believe and trust in his son Jesus Christ. It is not by any human achievements or merits, but by God's gracious election of his people. For God demands nothing from his people in order that people might be justified, but he freely, out of his grace, grants forgiveness of sins to all who confess Christ as their saviour. This righteousness is passive, since it is freely given to us by the Holy Spirit (Luther 1963:4-6). On the other hand, those who try to justify themselves by works sink deep into their sins because no one is able to please God since the fall of man. Nothing in the Law is able to justify man before God. The civil and the ceremonial parts of the Law, and the Decalogue, are unable to put us right with God, for it is not by our human works that we are justified but by the grace of God. Even works done in fulfilment of God's command do not justify us (Luther 1963:122). On this account, Luther opposed the Roman Catholic teaching of justification which they attributed not only to faith, but also to certain works like buying of indulgences, chastity, obedience, and living a life of poverty. This was contrary to the truth of the Gospel, as Luther (1963) states:

The truth of the Gospel is this, that our righteousness comes by faith alone, without the works of the Law. The falsification or corruption of the Gospel is this, that we are justified by faith but not without the works of the Law. The false apostles preached the Gospel, but they did so with this condition attached to it. The scholastics do the same thing in our day. They say that we must believe in Christ and that faith is the foundation of salvation, but they say that faith does not justify unless it is 'formed by love'. This is not the truth of the Gospel; it is falsehood and pretence. (p. 8)

Luther related Paul's situation in Galatians to his own. For Luther, the false apostles in Galatia preached a gospel with a condition that Galatian non-Jews accept and practise works of the Law in order that they might be justified. Luther read his own sixteenth-century context into Paul's context. For Luther, this was similar to the teaching of the Roman Catholic Church, namely that a good work done before justification earns the doer a 'merit of congruity', 2 whereas a work performed after justification earns the doer eternal life by the

2.This was a scholastic doctrine of merit and grace which taught that God gives grace to man after he has done a good work. Since such work is not contrary to God's Law but according to the Law of God, God rewards such a work with his grace. Good but according to the Law of God, God rewards such a work with his grace. Good
works were therefore encouraged among the people because they would earn works were therefore encouraged among
them grace before God (Luther 1960a:123). 'merit of condignity'. ${ }^{3}$ This teaching of the Scholastics rendered Christ useless because, according to them, salvation could be achieved by human powers (Luther 1963:124; cf. Gl 2:21). If there is a possibility of doing a work that pleases God and merits grace by the 'merit of congruity', and once the person has received grace does a work that earns him or her eternal life by the 'merit of condignity', why would they need grace, kindness and forgiveness of Christ? Christ has become altogether useless if one has the ability and power to do works that will not only please God, but also earn them eternal life (Luther 1963:124-125). Therefore, Luther believed that no work of man is able to justify him before God. For since the fall no one is able to do works that are pleasing to God or that lead to one's justification. Even though people are capable of moral deeds (Luther 1963:123), these works are only for the stability of society and not to justify humans before God (Luther 1963:124).

What then is the use of the Law? Why was it given? Although the Law has nothing to do with matters of justification, Luther believed that it was given for a purpose. The Law, according to Luther, has a two-fold purpose. Firstly, the Law has to restrain the wicked and uncivilised by threatening them with punishment (Luther 1963:274-275). This is the civil use of the Law as found in the magistrate's court designed to maintain peace and to preserve order in a given society. Those who wish to break the Law are restrained, not by their own powers but because of fear of punishment. People refrain from theft, murder, and other sins because they are afraid of the punishment of the Law, for the sword awaits anyone who breaks the Law. This is the civil righteousness that helps people to have respect for one another and promotes peaceful living among the people (Luther 1963:308-309).

Secondly, the Law multiplies transgressions (Luther 1963:309). This is the theological use and the 'primary purpose of the Law of Moses' (Luther 1963:309). The Law, on the one hand, multiplies sin in the human conscience and thereby burdens it with God's judgment and condemnation. The Law reveals man's misery, his unrighteousness, shamefulness, wickedness and contempt for God, deserving nothing else but God's wrath and punishment (Luther 1963:309). The Law reveals to man that he has not done what God requires him to do, and that he therefore deserves to receive God's punishment. With its terrors, the Law humbles the sinner and prepares him or her to receive the grace of God. When a sinner is terrified, he or she is driven to find mercy in Christ (Luther 1963:126). In other words, just like Augustine (1887:221) said, the Law discovers the disease in the human heart but it does not provide a cure. The Law as a schoolmaster (Gl 3:24) helped to teach, instruct and chastise Israel until Christ came. By its whipping, the Law trained and educated the Israelites in order that they would enjoy liberty when the promised Seed came (Gl 3:19; see Augustine 1887:221).

3.The 'merit of condignity' was a belief that God rewards eternal life to the person who has been justified was a belief that God rewards eternal life to the person who has been justified because of the good work one does. In this case God is in
debt and he is obliged to reward eternal life to the performer. This work performed in grace pleases God and earns the person eternal life (Luther 1963:124). 
On the other hand, those who claim to be righteous because they do not kill, steal or commit adultery are driven out of their comfort zone by the Law. Just as the Israelites were summoned out of their tents to Mount Sinai where they received the Law in a terrifying encounter with thunder, lightning, smoke and the burning mountain, even those who claim to be righteous because they have kept the Law (Ex 19:8) are brought to trembling and despair. After such a terrifying encounter with God, even those who thought to be righteous and holy were terrified and drew back, and requested Moses to speak to God on their behalf: 'Speak to us yourself and we will listen. But do not have God speak to us or we will die' (Ex 20:18, NIV). They could not endure the sight of God because of their sin. This is the second function of the Law: to terrify, threaten with God's anger, and to hammer all self-righteousness, driving the sinners out of their comfort zones in order that they may seek mercy from Christ (Luther 1963:309-311).

These are the reasons why the Law was given. It was not given as a means through which people might be justified, but that through it people may recognise their sins and come to Christ with thanksgiving (Luther 1963:329; see also Augustine 1992:22-24). Therefore, the work of the Law as custodian (Gl 3:24) has come to an end with the coming of Christ. For the Law pointed to Christ through whom salvation is found. The requirements of the Law are no longer binding on Christians, because they have put their faith in Christ to whom the Law pointed (Luther 1963:316-317).

Do we then abrogate the Law because its purpose ended with the coming of Christ? Luther does not argue that we abolish the Law because its time has ended. For Luther the Law helps to humble the sinner and prepare him or her to yearn for the grace of God (Luther 1963:327-328). Once sinners realise how sinful they are, they are forced by the Law to confess that nothing good dwells in them. In this way the Law has the function to prepare a sinner to receive God's grace in Christ (Luther 1963:238-239). Christians, therefore, need to hear the Law as long as they still live in this world. In his theses Against the Antinomians Luther (1971) argued:

For who could know what and why Christ suffered for us without knowing what sin or Law is? Therefore the Law must be preached wherever Christ is to be preached, even if the word 'Law' is not mentioned, so that the conscience is nevertheless frightened by the Law when it hears that Christ had to fulfil the Law for us at such great a price. Why, then, should one wish to abolish the Law, which cannot be abolished, yes, which is only intensified by such an attempt? For the Law terrifies me more when I hear that Christ, the Son of God, had to fulfil it for me than it would were it preached to me without mention of Christ and of such torment suffered by God's Son, but were accomplished only by threats. For in the Son of God I behold the wrath of God in action, while the Law of God shows it to me with words and with lesser deeds. (p. 113)

For Luther, Christians would not appreciate the work Christ has done for them if the Law was not preached. Therefore, where Christ is preached, the Law must also be preached.
Moreover, Christians are not without sin, for a Christian is simul iustus et peccator. Although Christians have been redeemed from the curse of the Law by faith in Christ, they still live in a sinful world. Christians are not without sin, but they are counted righteous because of faith in Christ. Whereas the new man believes, loves and trusts in God above all things, the sinful nature still clings to the desires of the flesh, of the world, and of the devil. A Christian, therefore, needs the Law to mortify this sinful nature and to reveal to man the need for Christ (Luther 1957:360-364; see also Althaus 2007:16-17).

In his sermon on Exodus titled 'How Christians should regard Moses' (Luther 1960b:169), Luther points out three reasons why the Law should be preached among Christians. Firstly, although the Law that was given to Moses was temporal and its function applied only to Israel, it is still a good example of how a government should rule. Moses represented a good government from which the civil government can borrow a leaf on how a just government should exercise its powers. The Mosaic Law also contains the natural Law that God has implanted into the human heart. To honour God, not to steal, and not to murder, is the Law everyone needs to observe for good living (Luther 1960b:169). Secondly, the Law of Moses contains pledges and promises of God about Christ (Luther 1960b:169). These promises cannot be found in the Law of nature, but only in the Law of Moses. In the Law God promises his Son to be born and to die for the sins of the world. This is the comforting news of the Gospel that strengthens a weak faith (Luther 1960b:169). Thirdly, the Law contains 'beautiful examples of faith, love, and of the cross, as shown by the fathers' (Luther 1960b:173). From these examples we learn to trust and love God, and also learn of what happened with the unfaithful Cain and Esau, and how God punished them for their sins. In these examples we are taught what to expect for our actions - punishment or blessings (Luther 1960b:173). For these reasons, therefore, the Law must be preached among believers.

\section{The third use of the Law}

In addition to the two-fold use of the Law described by Luther, the Lutheran church teaches a third use. This is described in Article Six of the Formula of Concord. This use of the Law has to do with Christian living: how Christians use the Law in their lives of faith. But the third use of the Law has not found favour by Lutheran theologians and teachers across the board. Some oppose this use of the Law mainly for two reasons. Firstly, some theologians argue on the basis of the terminology employed: Gerhard Ebeling (1963:62-65), for example, argues that Luther neither taught this use nor employed the terminology triplex usus legis in his works. Secondly, others argue that Christians do not have to adhere to the Law because their lives are directed by the Spirit. Gerhard Forde (1997:232) argues that the Law has no place in the life of a believer because it demands something that the believer has already fulfilled. When believers have faith in Christ, the Law no longer demands anything from them; rather, it has come to an end in Christ. The Law only comes into effect once the person has failed to comply with 
God's will. The person has altogether fallen from God's grace and is therefore in need of the Law. However, as long as the person remains faithful to God's will, he does not need the Law (Forde 1997:182). ${ }^{4}$ Werner Elert also disputes the third use of the Law. He denies the use of the Law as a guide to Christians, arguing that the new man of faith does good works out of new obedience. For Elert (1967:11) the Law always accuses (lex semper accusat). The Law informs man that God gives mercy to those who fulfil it, yet this fulfilment is impossible (Elert 1962:36). Man escapes this daunting task of the Law only if he seeks refuge in the risen Lord Jesus Christ who transforms the old person into a new being. The Law only convicts the new being of his sin in order to drive him back to Christ and not to guide him to do good works (Elert 1957:285, 1967:13). ${ }^{5}$

Despite the opposition by some scholars, the third use of the Law remains the teaching of the Lutheran church to which the Lutheran Church of Uganda subscribes. The Law does not only represent the accusing power of God, but it is also God's immutable will that must be maintained, not only among the unregenerate and impenitent but also among the converted Christians. This is what Article Six of the Formula of Concord teaches regarding the third use of the Law:

We believe, teach, and confess that, although people who truly believe in Christ and are genuinely converted to God have been liberated and set free from the curse and compulsion of the Law through Christ, they indeed are not for that reason without the Law. Instead, they have been redeemed by the Son of God so that they may practice the Law day and night (Ps 119:1). For our first parents did not live without the Law even before the fall. This Law of God was written into their heart, for they were created in the image of God. We believe, teach, and confess that the proclamation of the Law is to be diligently impressed not only upon unbelievers and the unrepentant but also upon those who believe in Christ and are truly converted, reborn, and justified through faith. (eds. Kolb \& Wengert 2000:502)

The teaching on the third use is the teaching about Christian living (cf. Ebeling 1985:249). It is concerned with how a believer lives his life with regard to the Law, which is God's unchangeable will. For the Law can never be done away with as long as one lives in this world. The Law helps in illuminating the way of believers for two reasons: firstly, that they may not attribute their good deeds to their own piety, and secondly, to compel the old Adam not to act according to his own sinful nature, but to subject himself to the Spirit (eds. Kolb \& Wengert 2000:502-503). It should be noted, however, that the good works done by a Christian are not attributed to the Law, but to the Spirit who enables its doing.

4.Gerhard Forde's discussion is based on the distinction between the old age and the new age. He believes that faith in Christ is the new age which has nothing to do with the old age, and since the Law belongs to the old age, it should therefore not bothe the person of the new age. Although the person lives in the same ages, the Law does not bother him as long as he remains in faith in Christ. It is only when he has fallen from God's grace that he becomes subjected to the Law (Forde 1997:225-227).

5.Werner Elert believes that the Law has come to an end in Christ and that the only use that remains is the accusing force which is the imperative to avoid evil. The Christian enjoys the freedom in Christ and does the good works out of new obedience. Although the Christian remains saint and sinner, insecure, anxious and fearful because he is still in this life, he overcomes these fears of the wrath of God with the 'word and reality of forgiveness and freedom' (Elert 1957:285, 291). For with the 'word and reality of forgiveness and freedom' (Elert 1957:285, 291). For
Elert, ' $[t]$ here is no situation imaginable, so long as the Law reigns over us, where it Elert, ' $[t]$ here is no situation imaginable, so long as the Law r
would not exercise this accusatory function' (Elert 1967:13).
Although the Law lights up the way of a believer, he or she does not do the will of God out of coercion and compulsion of the Law, but out of a free and merry spirit (Malysz 2004:212; Murray 2002:25). ${ }^{6}$ Faith is not only concerned with God, but it also has consequences before the world, which it manifests through action (Ebeling 1985:249). Faith must be lived and takes action in life as Paul says in Galatians 5:6, 'faith expressing itself in love'. Faith that frees a Christian from the Law expresses itself in love and service to the neighbour. This is true of the Lutheran Church of Uganda.

\section{The Law in the Lutheran Church of Uganda}

Even though the Church of Uganda calls itself 'Lutheran', it comes from a context that is culturally and socially different from that of Martin Luther and most other Lutherans in the rest of the world; their social and cultural identity has aspects not shared with the rest of the world. For this reason, it is important to determine how they understand and interpret the Law.

The Lutheran Church of Uganda understands the Law to be God-given. They believe that the Law was given to Israel as the means of life for God's people. Israel, as the people of God, were to abide by the whole Law that God gave them through his servant Moses. Therefore, there was no excuse for the Law's disobedience. The Law has to be preached every time a sermon is delivered. The Law is not a question of choice, but of urgency, for the word of God is Law and Gospel.

The Law, according to the Lutheran Church of Uganda, was given for this purpose, the same purpose it plays in the church today:

1. The Law is a curb. The Law deters, instils fear and brings discipline in the person who hears it. The hearers of the Law stay away from committing sin because the Law threatens to punish them. Therefore, people stay away from sin not because they want to, but because the Law threatens them with all sorts of punishments. This is good because the Law restrains human wickedness.

2. The Law is a mirror that reveals the sinfulness of believers. It is through the preaching of the Law that one becomes aware of one's sins. The Law reveals what deeds, how and in what ways a believer has transgressed the will of God. It reveals to believers that they have not done what God wants them to do. They recognise that they are sinful, thus driving them to seek God's grace found in Christ. The Law when it is preached acts in the same way as the mirror that one looks in: it allows one to recognise what one looks like. The Law exposes man for who he is.

6.Malysz (2004) highlights how important the Law is for Christian living. He asserts: 'Even a cursory glance at the New Testament will reveal a strong emphasis on Even a cursory glance at the New Testament will reveal a strong emphasis on Christian living. Believers are encouraged to "live a life worthy of the calling you have received" (Eph 4:1). As God's beloved children, they are to be "imitators of God," living "a life of love, just as Christ loved us and gave himself up for us as a fragrant offering and sacrifice to God" (Eph 5:1-2). The richness of expression is quite staggering. For the most part, however, the emphasis is conveyed through admonitions whose sense of immediacy reflects the crucial link between Christian life and Christ's atoning sacrifice on the cross as its source and driving force' (p. 212). 
It reveals all the flaws and unrighteousness and the inability to do the will of God. The Law brings guilt and condemnation, driving the sinner to seek help from outside of him, which is only found in the Gospel of Christ. The work of the Law is therefore to produce guilt and condemnation so that the guilty and condemned persons may repent of their sins and be reconciled with God through the Gospel in Christ Jesus.

3. The Law is a guide. The Lutheran Church of Uganda believes the Law describes what Christians are to do and what they are not to do. The Law is a measure of life by which Christians are to live. It describes the kind of behaviour Christians are to practise in this world. Without the Law one would not be able to differentiate between a Christian and a non-Christian, for Christians are expected to live an exemplary life desired by unbelievers. They are the light of the world (Mt 5:13-16). The Law guides Christians as they go about their lives here on earth.

For these reasons, the Law must be preached as often as possible whenever the word of God is preached. The Law is to be preached before the Gospel in order that after the hearers have been crushed and frustrated by the threats, guilt and condemnation of the Law, they may find consolation in the comforting words of the Gospel that Christ has fulfilled the Law for them and forgives their sin freely through faith. In the Gospel Christ speaks to the broken-hearted and the distressed, and says to them: 'Believe in me for I have borne the guilt of the Law for you'. The troubled consciences of the people are comforted with this good news. The despairing hearts are consoled when they hear that Christ forgives their sins, not on account of what they have done, but on account of faith. After the Law has threatened to punish them because of what they have done and have not done, the comforting news of Christ comes to them and rescues them from their misery. They must first recognise their misery and their inability to save themselves in order that they may appreciate what God has done for Christians in his son Jesus Christ.

\section{Retribution or punishing sinners}

The Law becomes more severe especially when there is public sin committed by a Christian in the church. Those who have sinned need to hear the full force of the Law. They need to hear that God is not pleased with them and his wrath is upon them in order that they may recognise their sin and repent of their wrongdoing. However, it does not end there. A Christian whose sin has become public is punished by the congregation to which he or she belongs. Christians whose sin is public are given some kind of punishment, like withholding the sacraments for a certain period of time, forbidding them to take up any office in the church, undergoing counselling, and even being excommunicated if they have failed to take responsibility for their $\sin$. The reason for punishing sinners is to bring them back to repentance and to teach a lesson to others. This practice aims at restoring the fallen Christians back into the fold of God, and not to alienate them from the rest of the community.
The Lutheran Church of Uganda does not excommunicate every sinner, but follows Jesus' steps described in Matthew 18 in bringing back a brother who has sinned. It is only after a brotherly reconciliation has failed that such a sinner is excommunicated. Even with excommunication it does not mean that a Christian has been banned from the church. He or she can come to church every Sunday but they will not be counted as members of that particular church; instead, they are treated as visitors. However, the congregation takes responsibility in reaching out to such a person in order that he or she may recognise their sin and be reunited with the community of believers. Withholding sacraments, forbidding them to take up offices, and counselling apply to those who have recognised their sin and have shown willingness to repent. Excommunication applies to the hard-hearted who show no remorse for what they have done.

The practice of punishing sinners is not provided for in the Lutheran confessions. Once sinners have recognised their sins and have repented, they are forgiven instantly. There is no condition to forgiveness. This is true even in the Lutheran Church of Uganda. They recognise that we are not put right with God because of our own works but by faith alone in Christ Jesus. A sinner who repents of his or her sins is forgiven regardless of what he or she has done.

The practice of punishing sinners is not to be understood as payment for what someone has done, because punishment does not correct the wrong committed nor should it be confused with the first use of the Law, which is to threaten, instil fear and bring discipline among the unregenerate and the unconverted. The practice of punishing sinners is different from the first use of the Law. Whereas the first use of the Law applies to the unregenerate and the unconverted, punishing sinners applies to the regenerate and the converted who have fallen from the grace of God because of sin. Sinners are brought to the knowledge of their sins through the preaching of the Law (the second use) and once they have acknowledged their sin, the congregation to which they belong holds them responsible for the sins they have committed. Where then does the practice of punishing sinners come from?

\section{Cultural influence}

The practice of punishing sinners is grounded in the African culture. Punishing a person who disregards the cultural rule and norm is imbedded in the African culture of dealing with crime and punishment. Every African society has its own rule of law according to which community members have to conduct themselves. Certain individuals within a community in most cases the elders - are tasked with making sure that the rule of law is maintained (see Hangmann 2007:31). In case of transgression of the community law, elders are responsible for restoration of sanity. This restoration follows specific procedures as laid down by the community. For example, if a culprit has trespassed against his neighbour, he must appease his neighbour, not only by apologising, but also by paying some kind of compensation (Murithi 2006:21). 
A transgression by one individual affects the whole community. It is not about the culprit and the victim or the culprit's family and the victim's family, but the whole community is affected by what an individual has done. This is because Africans believe in a communal life. Africans, especially the Bantu-speaking people in Eastern, Central and Southern Africa practise what is called Ubuntu. ${ }^{7}$ The concept of Ubuntu is that 'a person is a person through others' (Murithi 2006:17; Tutu 1999:34-35). Everyone is connected to everyone else in the community, and what happens to one person affects his neighbour and every member in that community. Ubuntu practises communal life. The concept of Ubuntu ensures social cohesion, because everyone in the community cannot exist by him or herself, but co-exists with others in the community. Therefore, everyone is responsible for everything that happens in the community. When one person infringes on the rights of another person, the whole community is affected because Ubuntu emphasises communal life. In such a case, the community must be involved in resolving the matter (Murithi 2006:18-19). Public participation in conflict resolution is a very important component in the concept of Ubuntu, because everyone in the community is as important as the other although there might be some differences in social standing. Public participation ensures general satisfaction as everyone's opinion is taken into consideration. Certain procedures are followed in conflict resolution: the public ensures that the culprit takes responsibility for what he or she has done; the culprit is encouraged to show genuine remorse and to repent of his or her wrongdoing; the culprit must ask for forgiveness and the victim is encouraged to forgive; the culprit is required to pay some kind of compensation to the victim, after which reconciling the two parties begins. Many communities in Africa continue to apply this peace-making process, for example in Rwanda and Uganda. ${ }^{8}$ Involving the whole community seems fair because everyone is affected. African culture is an inclusive society. No one exists on his or her own. This is what Ubuntu is all about.

The concept of Ubuntu, however, does not favour community over the individual. It does not stress the importance of the

7.Desmond Tutu (1999), in describing Übuntu, says: 'Übuntu is very difficult to render into a Western language. It speaks of the very essence of being human. When you want to give high praise to someone we say, "Yu, u nobuntu", "Hey, he or she has Ubuntu". This means they are generous, hospitable, friendly, caring, and compassionate. They share what they have. It also means my humanity is caught up, is inextricably bound up, in theirs. We belong in a bundle of life. We say, "a person is a person through other people". It is not "I think therefore I am". It says rather: "I am human because I belo". I participate, I share. A person with Ubuntu is open an human because I belong. I participate, I share. A person with Ubuntu is open and available to others, affirming of others, does not feel threatened that others ar able and good; for he or she has a proper self-assurance that comes with knowing humiliated or diminished, when others are tortured or oppressed, or treated as if they were less than who they are.' (pp. 34-35)

8.This form of conflict resolution has been used in Rwanda in order to resolve the tensions between the Hutus and Tutsis. The Gacaca, as it is locally known, is a traditional justice system used to try the perpetrators of the 1994 Rwanda genocide. In this peace process the community encourages the culprits to accept responsibility for their actions and the victims are involved in determining the kind of compensation the culprits are to pay in order that they might be reintegrated into the community (Murithi 2006:16). The same process has also been used in Northern Uganda to restore peace and harmony among the victims of the political instability by the Lord's Resistance Army (LRA). Mato Oput, as the Acholi call it, is a instability by the Lord's Resistance Army (LRA). Mato Oput, as the Acholi call it, is conflict resolution process where the community is involved in finding solutions to end conflict and to promote peace and social solidarity. The Mato Oput is headed by the council of elders composed of both male and female members and it involves the whole community whenever there is an issue to be resolved. It is believed that everyone in the community is somehow related to either of the parties involved in the conflict. Therefore, to have social consensus the whole community needs to be involved in finding solutions to the problem the community faces (Murithi 2006:24). community to the extent that the individual is alienated or dehumanised. Ubuntu values every individual. Khoza (2011) writes:

Ubuntu as a life orientation is opposed to rugged individualism. Neither is it comfortable with collectivism where the latter stresses the importance of social unit (group, community, society) to the point of depersonalising the individual. Ubuntu respects the individual. Ubuntu places great importance on working for the common good, on belonging to a group, an association, a corporate - in fact on every human being as an integral member of the human race and its institutions. (p. 446)

This is where the Lutheran Church of Uganda gets its practice from. Punishing sinners is an African way of dealing with conflict in a given community. A person who has committed sin must take responsibility for his or her actions and also pay some kind of compensation. The Lutheran Church of Uganda integrates culture into the practice of the Law. Because their sins tarnish the name of the whole church and not only the name of an individual, sinners need to compensate the church by accepting punishment. By accepting punishment, the sinner acknowledges his or her sins and feels sorry for having brought the whole church into disrepute. With punishment, the church portrays her intolerance towards sin. This gesture sends a message even to those who have not sinned, warning them of the same consequences if they ever sinned, for no one wants to be shamed publicly.

Where is justification by faith alone in all of this? What justifies? Is it punishment and compensation? It must be noted that the church does not think that people are justified by this practice. No human work is able to justify us before God. The Lutheran Church of Uganda confesses Article IV of the Augsburg Confession (McCain 2006):

Our churches teach that people cannot be justified before God by their own strength, merits, or works. People are freely justified for Christ's sake, through faith, when they believe that they are received into favour and that their sins are forgiven for Christ's sake. By his death, Christ made satisfaction for our sins. God counts this faith for righteousness in his sight (Romans 3 and 4 [3:21-26; 4:5]). (p. 36)

The Lutheran Church of Uganda believes and teaches that justification is beyond human capability. God works justification in those who believe in his son Jesus Christ without any human works. Punishing sinners is a cultural practice that aims at maintaining a horizontal relationship between Christians. It also brings social cohesion and respect for one another and also helps Christians to live within the limits of the Law, because no one would want to find himself on the wrong side of the church community. It is the cultural identity of the people of Uganda that becomes integrated in the interpretation of the Law. This concerns only the African identity of the Lutherans in Uganda as Africans. It is on the ethnic level, which has nothing to do with justification before God. Being African and Lutheran cannot be lived separately; therefore, these two must find a way to be integrated. However, God's word remains supreme. The word of God 
cannot be compromised by those practices that are opposed to it. Where this happens, the word of God must take precedence; nevertheless, people are free to exercise their culture as long as its practices do not interfere with the truth of the Gospel.

\section{The Galatian context}

The cultural influence in preaching the Gospel is not peculiar to the Lutheran Church of Uganda. It is also an issue that Paul deals with in his ministry, especially in his letter to the Galatians. In reading Galatians, one sees Paul faced with the problem of identity clash. The Jews, on the one hand, wanted the Galatian non-Jews to practise Jewish culture if they were to be counted among the people of God. They wanted nonJews to practise circumcision, dietary laws and other Jewish practices if they were to be received into the people of God. We see Paul clashing with his fellow Jews in Jerusalem and in Antioch (Gl 2:1-14), because they wanted to impose distinctively Jewish practices onto Galatian non-Jews. ${ }^{9}$ Jews understood the people of God to be those who possessed the Law, not that they were justified by it, but because God had chosen Israel and had given them the Law as a means of remaining in the covenant. ${ }^{10}$ For Jews knew that God had elected them as his own people not because they deserved it, but because of his grace (cf. Das 2014:246). Even though they had the Law and lived within the requirements of the Law according to the covenant, they were not justified, for justification is only by faith (Das 2014:246). The Jews also knew that it was not by their own powers that they were able to do what the Law required. They still relied on God's grace for this fulfilment (Das 2014:247). ${ }^{11}$ With this Jewish self-understanding, Paul refutes their position in Galatians 2:15-16. He reminds his fellow Jews that it is not by the works of the Law that they are justified. For if it was so, then they (Jews) would not have believed in Christ Jesus. But because the works of the Law do not justify, they have believed in Christ in whom justification is found. Therefore, being justified has nothing to do with the possession of the Law but having faith in Christ. The Galatian non-Jews thus

9.The works of the Law, for example, circumcision, dietary laws and the Sabbath had become distinctively Jewish. They were boundary markers distinguishing their practitioners as Jews and marking them off from the rest of the people. Although these practices were marks of the covenant that God had made with Israel, they had become associated with Jewishness (Dunn 2008:110-111).

10.Sanders calls this relationship 'covenantal nomism', which he defines as 'the view that one's place in God's plan is established on the basis of the covenant and that the covenant requires as the proper response of man his obedience to its the covenant requires as the proper response of man his obedience to its Obedience maintains one's position in the covenant, but it does not earn God's grace as such' (Sanders 1977:75, 420). See also Räisänen (1992:114).

11.The Dead Sea Scrolls testify to Israel's dependence on God for the fulfilment of the Law: 'But I know that justice [righteousness] does not belong to man nor the perfect path to the son of man. To God Most High belong all the facts of justice [righteousness], and the path of man is not secure except by the Spirit which God creates for him ... for I have remembered my faults ... I said 'For my sin I have been barred from your covenant'. But when I remembered the strength of your hand and the abundance of your compassion I remained resolute.... For you have supported me by your kindness and by your abundant compassion. Because you atone for my sin and cle [anse man] of his faults through your justice [righteousness]" atone for my sin and cle [anse man] of his faults through your justice [righteousness] (1QH XII [=IV], in Martinez 1994:30-31, 34-37). Again in 1QS XI, 'The mercies of God shall be my salvation always; ... he will draw me near in his mercies, and by kindness set in motion my judgment; he will judge me in the justice [righteousness] of his truth, and in his plentiful goodness always atone for all my sins, in his justice [righteousness] he will cleanse me from the uncleanliness of the human being and from the sins of the son of man, so that I can extol God for his justice [righteousness] (1QS XI, in Martinez 1994:12-15). cannot be required to practise the works of the Law in order to be justified. Faith in Christ is enough. With the coming of Christ, the work of the Law as an identity marker for the people of God no longer stands. The new covenant which is faith in Christ expands beyond Jewish boundaries. In other words, there has been recategorisation (Esler 2003:54). The people of God are no longer those who possess the Law, but those who have faith in Christ (Dunn 2008:113). Faith in Christ is the new identity of the people of God (G1 3:28; Van Eck 2009:75). The people of God in the new covenant are an inclusive group of Jews and non-Jews. Ethnic boundaries have been abolished and now everyone is admitted on account of faith irrespective of who they are (Gl 3:28; Van Eck 2009:79).

What then becomes of different ethnic groups? Does faith in Christ do away with ethnicity? ${ }^{12}$ Although Paul disparages the Law and its works in Galatians, he does not deny its social function especially to the Jews. The concern for Paul was using the works of the Law (circumcision, dietary laws and the Sabbath) to keep non-Jews out of the grace of God. Paul did not expect Jewish Christians to abandon their Jewish practices because of faith. ${ }^{13}$ Even with faith in Christ Jews would remain Jewish and non-Jews would remain Gentile. Faith in Christ does not remove social boundaries nor does it eliminate ethnicity. Even Paul remained a circumcised Jew although he no longer saw it as an advantage over the nonJews (Phlp 3:3-9). His mission to the non-Jews had made him to live among the non-Jews and therefore he had to acclimatise himself with Gentile practices as long as they did not interfere with the truth of the Gospel. That is why Paul speaks of

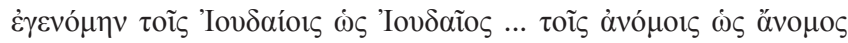
(1 Cor 9:20, 21). For Paul, ethnicity counts for nothing. He is therefore free to be like the Jews when he is among the Jews just like he becomes lawless when among those without the Law. What counts for Paul is just one thing, which is faith in Christ. The people of God are not to be identified by their ethnicity but by faith in Christ (Nebrada 2008:34-35). Jews as well as non-Jews can remain the way they are and continue to practise their culture as long as these cultural practices do not interfere with the Gospel of justification by faith. Only those practices that contradict the Gospel are to be eliminated. Being the people of God has nothing to do with ethnicity; yet, ethnicity remains the 'vehicle for the [G]ospel at a specific place and time' (Van Eck 2009:79).

\section{Conclusion}

The understanding and interpretation of the Law in the Lutheran Church of Uganda does not differ significantly from Luther's and the general Lutheran teaching. The Law is understood to be useful in three ways, that is, to restrain the wicked and uncivilised by threatening them with punishment,

12.Cromhout (2007:82) defines ethnicity as 'a form of social identity, referring to a collectivity of individuals who ascribe to themselves and/or by others, a sense of belonging and a common cultural tradition'.

13.Räisänen (1992:123) argues that although Paul did not tell his fellow Jews to abandon Jewish practices, he would expect them to do exactly that, whenever these practices interfered with Paul's gospel to the Gentiles. 
to reveal the sinfulness of man, and to guide Christians in a God-pleasing life. These are the same uses of the Law according to Article VI of the Formula of Concord. The Lutheran Church of Uganda differs only regarding punishing sinners for the wrong they have committed. This practice is embedded in the African culture of Ubuntu where a person who has done wrong towards his neighbour must take responsibility for his actions and pay compensation to the victim of his crime. This is an aspect of African culture that the Lutheran Church of Uganda integrates into the practice of the Law. However, the Lutheran Church of Uganda understands that justification is solely dependent on God's grace. Even compensation does not yield God's favour but only benefits the community to which the Christian belongs. This practice is what makes them African and differentiates them from the rest of the world.

This practice can be compared with what Paul faces in Galatians. The context of the people plays a significant role in understanding and interpreting the word of God. The social and cultural context of a particular group of people must be considered for a better understanding of what God requires of that particular people. Although the social and cultural context of the Lutherans in Uganda differs significantly from that of the Jews at Paul's time, how Paul deals with the identity clash of the Jews and the non-Jews in Galatians helps us to understand the importance of the social and cultural context in preaching the Gospel. In disputing Jewish Christians who wanted their non-Jewish counterparts to adopt distinctively Jewish practices in order to be counted among the people of God, Paul does not tell his fellow Jews to abandon their practices. One is free to practise one's culture as long as it does not interfere with the truth of the Gospel. Jews would remain Jewish and non-Jews would remain non-Jews and continue to live within their cultural boundaries. However, they should not use these boundaries to bar others from God's kingdom. Our outward practices do not determine who the people of God are. For although Israel was marked by the works of the Law as the people of God, these no longer count in the new covenant. The people of God in the new covenant are those of faith regardless of their ethnicity. Faith in Christ remains the only identity marker of the people of God (Gl 3:28).

\section{Acknowledgements}

A lot of thanks go to the leadership and supervision of Prof. Dr Ernest van Eck who guided me in carrying out this research. I am truly grateful to him.

And to my family: I can never thank you enough for your patience, love, and support.

\section{Competing interests}

The authors declare that they have no financial or personal relationships which may have inappropriately influenced them in writing this article.

\section{Authors' contributions}

This research was conducted by E.E. (University of Pretoria) in the Department of New Testament, Faculty of Theology under the supervision of E.v.E. (University of Pretoria).

\section{References}

Althaus, P., 2007, The ethics of Martin Luther, transl. R.C. Schultz, Fortress Press, Minneapolis. Augustine, 1887, 'On the spirit and the letter', in P. Schaff, SLNPNF, vol. 5, pp. 354-430, The Christian Literature Company, New York.

Augustine, 1992, Confessions, transl. H. Chadwick, Oxford University Press, Oxford.

Brecht, M., 1985, Martin Luther: His road to reformation 1483-1521, transl. J.L. Schaaf, Fortress Press, Minneapolis.

Cromhout, M., 2007, Jesus and identities: Reconstructing Judean ethnicity in $Q$, Cascade Books, Eugene.

Das, A.A., 2014, Galatians, Concordia commentary, Concordia Publishing House, Saint Louis.

Dunn, J.D.G., 2008, The new perspective on Paul, rev. edn., Eerdmans, Grand Rapids.

Ebeling, G., 1963, Word and faith, transl. J.W. Leitch, SCM Press, London.

Ebeling, G., 1985, The truth of the gospel: An exposition of Galatians, transl. D. Green, Fortress Press, Philadelphia.

Elert, W., 1957, The Christian ethos, transl. E.H. Schroeder, Fortress Press, Philadelphia.

Elert, W., 1962, The structure of Lutheranism: The theology and philosophy of life of Lutheranism especially in the sixteenth and seventeenth centuries, transl. W.A. Hansen, Concordia Publishing House, Saint Louis.

Elert, W., 1967, Law and Gospel, transl. C.J. Schindler, Muhlenberg Press, Philadelphia. Esler, P.F., 2003, 'Social identity, the virtues, and the good life: A new approach to Romans', Biblical Theology Bulletin 33, 51-64.

Forde, G.O., 1997, On being a theologian of the cross: Reflections on Luther's Heidelberg disputation, 1518, Eerdmans, Grand Rapids.

Hangmann, T., 2007, 'Bringing the Sultan back in: Elders as peacemakers in Ethiopia's Somali Region', in L. Buur \& H.M. Kyed (eds.), State recognition and democratization of Sub-Saharan Africa: A new dawn for traditional authorities?, pp. 31-51, Palgrave Macmillan, New York.

Khoza, R.J., 2011, Attuned leadership: African humanism as compass, Penguin Books, Johannesburg.

Kolb, R. \& Wengert, T.J. (eds.), 2000, The Book of Concord: The confessions of the Evangelical Lutheran Church, Fortress Press, Minneapolis.

Luther, M., 1957, Luther's works, vol. 31, (Career of the Reformer I), transl. H.T. Lehmann, Fortress Press, Philadelphia.

Luther, M., 1960a, Luther's works, vol. 34, (Career of the Reformer IV), transl. L.W. Spitz, Muhlenberg Press, Philadelphia.

Luther, M., 1960b, Luther's works, vol. 35, (Word and Sacrament), ed. T. Bachman, Muhlenberg Press, Philadelphia.

Luther, M., 1963, Luther's works, vol. 26, (Lectures on Galatians), transl. H.T. Lehmann, Concordia Publishing House, Saint Louis.

Luther, M., 1964, Luther's works, vol. 27, (Lectures on Galatians), transl. H.T. Lehmann, Concordia Publishing House, Saint Louis.

Luther, M., 1971, Luther's works, vol. 47, (The Christian in Society IV), transl. H.T. Lehmann, Fortress Press, Philadelphia.

Malysz, P.J., 2004, 'The third use of the Law in light of creation and the fall', in C.A. Gieschen (ed.), The Law in Holy Scriptures: Essays from the Concordia Theological Seminary symposium on exegetical theology, pp. 211-237, Concordia Publishing House, Saint Louis.

Martinez, G.F., 1994, The Dead Sea Scrolls translated: The Qumran texts in English, E.J. Brill, Leiden.

McCain, P.T. (ed.), 2006, Concordia: The Lutheran confessions, Concordia Publishing House, Saint Louis.

Murithi, T., 2006, 'African approaches to building peace and social solidarity', African Journal of Conflict Resolution 6(2), 9-34.

Murray, S.R., 2002, Law, life, and the living God: The third use of the law in modern American Lutheranism, Concordia Publishing House, Saint Louis.

Nebrada, S.R., 2008, 'Have this mind: A socio-scientific reading of Philippians 2:5-11', PhD thesis, Department of New Testament Studies, University of Pretoria.

Räisänen, H., 1992, Jesus, Paul and Torah: Collected essays, Bloomsbury, New York, NY (JSNT suppl. ser. 43).

Sanders, E.P., 1977, Paul and Palestinian Judaism: A comparison of patterns of religion, Fortress Press, Philadelphia.

Stendahl, K., 1963, 'The apostle Paul and the introspective conscience of the West' Harvard Theological Review 56(3), 199-215.

Tutu, D., 1999, No future without forgiveness, Rider, London.

Van Eck, E., 2009, 'Inclusivity as the essential nature of the Gospel', HTS Theological Studies 65(1), Art. \#304, 10 pages. http://dx.doi.org/10.4102/hts.v65i1.304 